\title{
The Level of Students' Anxiety in Speech at Universitas Muslim Nusantara Al- Washliyah Medan
}

\author{
Yulinda Oktaviana Harahap ${ }^{1 *}$ and Yenni Rozimela ${ }^{2}$ \\ ${ }^{1}$ English Department FBS, Universtas Negeri Padang, Padang, Sumatera Barat 25131, Indonesia \\ ${ }^{2}$ English Department FBS, Universitas Negeri Padang, Padang, Sumatera Barat, 25131, Indonesia \\ *Corresponding author. Email: yulindaoktaviana@gmail.com
}

\begin{abstract}
The objective of the studies is to analyze of anxiety levels the students at sixth semester of English Department of Muslim Nusantara University in academic year 2020/2021. This research used a descriptive quantitative research design. The collected data were described and presented through a simple statistical formula in a descriptive explanation. The subject of the research was twenty-five randomly selected students from the English Department. The level of students' anxiety is rated by the FLAS (the Foreign Language Anxiety Scale) through a speaking test, which they needed to deliver their speech. Then, a questionnaire in this studies was adapted from the FLAS ( The Foreign Language Anxiety Scale) proposed by Horwitzh. The Foreign Language of Anxiety Scale (FLAS) contained 33 statements devide into three categories namely apprehension of communication, test of anxiety, and afraid of a bad assessment. This research found that 9,2\% of the students got very anxious level, $115,3 \%$ of the students were at anxious level, and 98,2 \% of them were categorized as middle anxious. For the result, it is found that there was not any participant in the level of relaxed and very relaxed. This research concluded that most of the students were having speech anxiety at the anxious level.
\end{abstract}

Keywords: Anxiety, Level, and Speech

\section{INTRODUCTION}

Having good English communication skills increase ones' chances in many fields. To have English communication skills, students have to have high-level proficiency in speaking. There are four skills in English which is speaking is the most crucial skill needed to be mastered. It is very important to have fluency in speaking skills to face the globalization era Students have to go through many process and ways of learning in target language.

Speaking English is important since it is very helpful for facing the globalization era. Speech is one way for students to practice their English speaking, to build their self-confidence, to share ideas, and to express themselves in public. Beebe [1] says that speech is such as a dialogue that students need to regulate his/her thoughts into words to be presented to the listener. Moreover, Byrms [2] points out that a speaker who able to communicate with their body language and their voice is a well public speaker. However, it is not difficult to be a public speaker. It is said that a good public speaking needs well preparation before he/ she standing out on the stage or speaks to a group. He /she must be ready with many things, even for unpredictable situation. Some important things to consider when speaking in public are structure, appearance and body language, voice behavior, audio-visual support, and question-and-answer sessions [3]. In his statement, Garies [3] mentions the use of audiovisual aids help the speaker convey thoughts and feelings in front of the audience.

Bueno et.al [4] say that speaking is the one of the most hard skills language the learners have to face. Even the students have learned the language for years, they still meet the difficulties to speak in real-time situations. Along with the process, the students are affected by internal and external factors which result in positive and negative impacts on the English learning process. The students cannot speak English. Students cannot speak well because they feel confused and sometimes because English not their first language. They feel anxiety, which is usually called language anxiety [5]. Rullu and Daburan [6] say that the students' anxiety is affected by their mother tongue; as a result, they have problems with English. Therefore, the students cannot actively share their message and knowledge since factors namely negative evaluation, communication comprehension, fear of negative evaluation, and minimum preparation.

Chan and $\mathrm{Wu}$ [7] determine that anxiety is a feelings of arrest and tension that are accompanied by or related with activation or stimulation of the autonomic 
nervous classification. Moreover, Muris [8] explains briefly the bodily symptom of anxiety which include vibrating hands, excreationing, difficulties with expirationing, unusual emotional in the chest, very fast heart worsting, feeling very ardent, unpleasant feeling in head, emotional nauseous, emotional very dizzy, and unpleasant emotional in the belly. In addition, Brown and Yule [9] explain that anxiety as a condition characterized by emotions of unease, frustration, selfdoubt, arrest, or tease. It's described the anxiety will attacks someone who will speak in front of the class by feeling those kinds of symtoms. For example, a student who feel anxiety, he/she will loses his/her ideas or topic when facing the audience or before standing in front of people.

Feelings of discomfort such as fear will undoubtedly upset students; they absolutely affect the study and student performance; anxious students feel difficulties in thinking clearly and make more mistakes. Additionally, anxiety makes students work harder finishing their tasks. It worries them and distracts their practice process.

According to Omrod [10], anxiety able to interfere with numorous areas of cognition in the understanding procedure. Students that are anxious has trouble paing attentin in class, properly processing advice, recovering information, and demonstrating what they have learned. Moreover, elements such as act setting, affective aspect, listening mastery, and feedback influence students' speaking achievement during speaking undertaking [11].

Ellis [12] categorizes three anxiety-related performances namely characteristic anxiety, state of anxiety, and position-specific anxiety. Characteristic anxiety about permanent people's personality trait and behavior that are difficult to change. He mentions that trait anxiety can appear in a non-threatening situation. He continues that it may be the person' $s$ characters. Meanwhile, state anxiety refers to a feeling of anxiety due to the change of one's emotional state caused by an external factor [13]. The last is position-specific. anxiety. It is brought on by certain condition or an activity in learning English [13]. It appears in a specific situation like examination, public speaking, or classroom participation [14].

In addition, Horwitzh and Cope [15] explain that a target language anxiety as a definite compound of selfcognizance, view, feelings, and behavior referring in class language understanding arising from the uniqueness of the language understanding operation. Moreover, Taysi [16] claims three main categories of students' opinions about the problems faced in using English. The first is limited vocabulary; it created students feel scared of contrasting misidentify in using vocabulary they have learned. Concerning the pronunciation. is the second problem; students are unsure of how to pronounce words and are afraid of mispronunciation. The last is a grammatical concern, studens are reluctant to speak English because they want to form grammatically accurate sentences and are afraid of making mistakes.

In addition, Horwitzh and Cope [15] describe three variables that contribute anxiety in speaking. There are three factors namely apprehension of communication, test of anxiety, and afraid of a bad assessment. 1) Apprehension of communication is students' failure to appropriately convey their thoughts and ideas, as well as a lack of understanding of the speech's topic, and loss the concept about the topic of the speech. 2) The fear of negative evaluation arises because of a favorable social impression in the eyes of others that is needed to be presented by a student [7]. The last is test anxiety that refers to apprehension about an academic evaluation or negative view about their language ability [17]. L. M [18] adds the the anxiety associated with participants cognizance of how observers, professors, classmates, or other could negatively evaluate them to assess or judge his/her English skill. The students worry about the bad marks from teachers and buddies. It may happen in any situation. The students can be more tactful in assessment-fact or envisioned of his/her buddies. Moreover, speaking in front of familiar audience will make students feel more pressure and the fear occurs sometimes uncontrolled.

The language learning outcome is affected by anxiety as one of psychological factor that has an important role. Several studies on speaking anxiety among students have been conducted, such as [19], [20], [21], [22]. They found that students experience various levels of target language anxiety. The students are anxious not only in the classroom but also outside of it, particularly when they utilize the language in real-life situations [23]. Another study mentioned that students experienced various levels of anxiety in different classroom activity. Confident students had low anxiety and believed they could perform well [24], while less confident students had higher anxiety and believed they could not perform well. Furthermore, Kim [25] found that the students in an foreign language discussions class had towering level of the anxiety than second language reading class. Meanwhile, [26], [27], [28] found that a significant speaking anxiety level was showed as the majority problems of the students.

Following the result of the previous research, many researchers have conducted studies related to the level of students' speaking ability in different classroom contexts. However, only a few researchers examined the anxiety level toward speech (monologue). Therefore, the researcher analyzed the level of students' anxiety in a speech at the English Class of Muslim Nusantara AlWashliyah Medan University in the academic year 2020/2021.

\section{METHOD}

This study utilized a descriptive quantitative research design. The collected data were described and presented through a simple statistical formula in a descriptive explanation. There were five classes in the 
sixth semester with a total of 125 students. Since the population in this research was more than one hundred students, random sampling was utilized to choice the samples by researcher. There were 25 students chosen as the samples. The instrument was a questionnaire which adapted from Horwitzh \& Cope (1986) consisting of 33 items. It contained foreign language students' anxiety namely are apprehension of communication, test of anxiety, and afraid of a bad assessment. The score from students' anxiety scale would range from 33 to 165. The anxiety levels begined from very anxious, anxious, middle anxious, relaxed, and very relaxed. Then, the data were analyzed by following two steps. The first step was using a Likert scoring by the FLAS (Foreign Language Anxiety Scale).

According to Oetting's Scale in [29] Foreign Language Anxiety Scale (FLAS) was divided into five levels starting from very relaxed up to very anxious. These levels are presented in Table I as follows:

Table I. Students' Level Anxiety of Speech

\begin{tabular}{|c|c|}
\hline Level of speech & Score \\
\hline Very Anxious & $124-165$ \\
\hline Anxious & $108-103$ \\
\hline Middle Anxious & $87-107$ \\
\hline Relaxed & $66-86$ \\
\hline Very Relaxed & $33-65$ \\
\hline
\end{tabular}

\section{RESULT AND DISCUSSION}

\section{1. Research Result}

\subsubsection{Student' anxiety Level in speech}

This part describes the data and the result of the fear level anxiety in speech. The data was collected from the students of the sixth semester of UMN- AW Medan. The result showed that the fear of students was divided into five different levels; very anxious, anxious, moderately, anxious, relaxed, and very relaxed.

Table 2. The Statistical Result of Level Anxiety in Speech

\begin{tabular}{|c|c|c|c|}
\hline NO & $\begin{array}{c}\text { The Level of } \\
\text { Anxiety in Speech }\end{array}$ & $\begin{array}{c}\text { Number of } \\
\text { learners }\end{array}$ & Rate \\
\hline 1 & very anxious & 3 & $9,2 \%$ \\
\hline 2 & Anxious & 12 & $115,3 \%$ \\
\hline 3 & Middle anxious & 10 & $98,2 \%$ \\
\hline 4 & Relaxed & 0 & $0 \%$ \\
\hline 5 & Very relaxed & 0 & $0 \%$ \\
\hline & Total & 25 & $100 \%$ \\
\hline
\end{tabular}

Table II displays that from the 25 students, shows that there were 3 students $(9,2 \%)$ of them were having $a$ very anxious level. Furthermore, there were 12 students $(115,3 \%)$ were having an anxious level, and 98,2 \% of students were having a middle anxious level. It is seen that no participant was at the level of relaxed and very relaxed. Thus, it was concluded the majority students were having speech anxiety at the anxious level.

\subsection{Discussion}

The finding found $115,3 \%$ of most of the students were having speech anxiety at the level of anxiety. This finding was supported by findings of research conducted by [30] who also found that most students were at the anxiety level in Foreign Language learning.

However, the current finding of this study did not support the previous result from who described learners experienced a moderate to high level in speaking anxiety. They examined the fourth-year English class students at three Universitas in Libya. In addition, results of their research describe that the low selfconfidence factor accepted the highest average attended by fear of bad evaluation and communication apprehension element. Other studies conducted by Alnahidh and Altalhab [32] , and Sugiyati and Indriani [33] found that the level of moderate in Foreign Language Anxiety Scale of participants in English Class. Any time, when they performed speaking in the class, they already dealt with the anxiety.

\subsection{Conclusion}

The aim of this research inquire to students' level anxiety in speech. The results showed that most of the students were having speech anxiety at the anxious level.

\section{AUTHORS' CONTRIBUTIONS}

It is hoped that the description will be used in this research can be a reflection for other researchers to do more study on anxiety especially the students' level anxiety in speech. In the next investigation there must be some methods of dealing with it. The other researchers have to discover strategies. To improve students ' ability to pronounce the language. Creating an appropriate classroom environment it also essential to assist in efforts to reduce anxiety. The students must find the ideal teaching environment in order to increase the teaching and learning process.

\section{ACKNOWLEDGMENTS}

A great appreciation for the lecturer who give many contributions in finishing this study especially the lecturer at English. Department. of Muslim. Nusantara Al-Washliyah Medan. I would you like also to thank to my advisor Prof. Yenni Rozimela, M.Ed., Ph.D. who help me in doing this study

\section{REFERENCES}

[1] S. A. Beebe, Public Speaking: An AudienceCentered Approach. Boston: Allyn and Bacon, 2009.

[2] J. H. Byrns, Speak for Yours. An Introduction to Public Speaking. Singapore: McGraw-Hill, Inc.., 1994.

[3] E. Gareis, Guidelines for public speaking. New York: Dept. of Communication Studies., 2006.

[4] A. Bueno, D. Madrid, and N. McLaren, TEFL in Secondry Education. Granada: Granada: Editorial Universitas de Granada, 2006. 
[5] U. M. Siagian, "An Analysis of Students , Anxiety in Speaking," J. Ilm. Progr. Stud. Pendidik. Bhs. Ingg., vol. 8, no. 1, pp. 3-9, 2017.

[6] S. M. Rullu and H. Daburan, "Speaking Problems of EFL Students at English Education Study Program in Muhammadiyah Luwuk University," BABASAL English Educ. J., vol. 1, no. 1, p. 10, 2020, doi: 10.32529/beej.v1i1.529.

[7] D. Y. Chan and G. Wu, "A Study of Foreign Language Anxiety of EFL Elementary School Students in Taipei Country. National Taipei County Teacher Collage," vol. 17, no. 2, pp. 287-320, 2004.

[8] Muris, "Children's Internal Attributions of Anxiety-Related Physical Symptoms: AgeRelated Patterns and the Role of Cognitive Development and Anxiety Sensitivity," Child Psychiatry, no. (41), pp. 535-548, 2010.

[9] Brown and G. Yule, Teaching Spoken Language: Aprroach Based On The Analysis of Connversational English. Cambridge University Press, 2000.

[10] J. E. Omrod, Educational Psychology: Developing Learne. Boston: Pearson Education, 2011.

[11] N. H. Tuan and T. N. (2015) Mai, "Factors Affecting Students' Speaking Performance at LE Thanh Hien High Schoo," Asian J. Educ. Res., vol. 2, no. 3, pp. 8-23, 2015.

[12] R. Ellis, The Study of Language Acquisition. Oxford: Oxford University Press., 1994.

[13] F. Fitriah and H. Muna, "Foreign language speaking anxiety: A case study at English departement students of IAIN Lhokseumawe and Al Muslim university," J. Ilm. Didakt., vol. 19, no. 2, pp. 141-158, 2019.

[14] J. Kurnia, "Anxiety in Learning English at SMPN 23 Pekanbaru." Pekanbaru: Unpublished Paper., 2008.

[15] E. K. Horwitzh and J. . Cope, Language Anxiety From Theory and Research to Classroom Implications. Englewood, New Jersey: Prantice Hall, 1986.

[16] E. Taysi, "A Study On Turkish EFL Students' English Speaking Anxiety.," Int. J. Lang. Educ. Teach., vol. 2198-4999, pp. 587-588 (diakses pada tanggal 08 Agustus 2017, 2015.

[17] H. Gregory, Public speaking for collage and Career, 2nd ed. New York: ITC Garamond Light By Ruttle, Shaw\& Watherill, Inc., 1990.

[18] L. M, "Anxiety in EFL Classroom: Causes and Consequences," TESL Report., vol. 39, no. 1, pp. 13-32, 2006.

[19] L. H. Lian and M. B. Budin, "Investigating the Relationship between English Language Anxiety and the Achievement of School based Oral English Test among Malaysian Form Four Students," Int. J. Learn. Teach. Educ. Res., vol. 2, no. 1, pp. 67-79, 2014.
[20] Kamridah, "Correlation between Level of Anxiety and Public Speaking Performance through Systematic Learning Approach in Foreign Language," Int. J. Sci. Res., vol. 5, no. 9, pp. 1658-1663, 2016, doi: 10.21275/ART20161991.

[21] T. Li, "Analysis on the Causes and Treatment of Public Speaking Anxiety," vol. 466, no. Isemss, pp. 514-518, 2020, doi: 10.2991/assehr.k.200826.103.

[22] A. Sjaifullah, "An analysis of EFL students' anxiety factors in speaking," Int. Res. J. Eng. IT Sci. Res., vol. 5, no. 3, pp. 43-48, 2019, doi: 10.21744/irjeis.v5n3.655.

[23] M. Tanveer, "Investigation of the factors that cause language anxiety for ESL / EFL learners in learning speaking skills and the influence it casts on communication in the target language .," A Diss., no. June, pp. 1-92, 2007, doi: 10.13140/RG.2.1.1995.1129.

[24] S. Matsuda and P. Gobel, "Anxiety and predictors of performance in the foreign language classroom.," System, vol. 32, no. 1, pp. 21-36, 2004.

[25] S. Y. Kim, "Questioning the stability of foreign language classroom anxiety and motivation across different classroom contexts.," Foreign Lang. Ann., vol. 42, no. 1, pp. 138-157, 2009.

[26] E. Debreli and S. Demirkan, "Sources and Levels of Foreign Language Speaking Anxiety of English as a Foreign Language University Students with regard to Language Proficiency and Gender," Int. J. English Lang. Educ., vol. 4, no. 1, p. 49, 2015, doi: 10.5296/ijele.v4i1.8715.

[27] C. Sutarsyah, "An Analysis of Student's Speaking Anxiety and its Effect on Speaking Performance," IJELTAL (Indonesian J. English Lang. Teach. Appl. Linguist., vol. 1, no. 2, pp. 143-152, 2017, doi: 10.21093/ijeltal.v1i2.14.

[28] T. Handayani, Y. Rozimela, and S. Fatimah, "An analysis of English-speaking anxiety experienced by the second year students of English Language and Literarture Department of Universitas Negeri Padang and its causal factors," J. English Lang. Teach., vol. 9, no. 3, pp. 580-592, 2020, doi: 10.24036/jelt.v9i3.44303.

[29] T. Mayangta, “'Students' Speaking Anxiety in an EFL Classroom'," pp. 24-29., 2013.

[30] G. Tridinanti, "The Correlation between Speaking Anxiety, Self-Confidence, and Speaking Achievement of Undergraduate EFL Students of Private University in Palembang," Int. J. Educ. Lit. Stud., vol. 6, no. 4, p. 35, 2018, doi: 10.7575/aiac.ijels.v.6n.4p.35.

[31] A. M. Toubot, G. Hock Seng, and A. Binti Atan Abdullah, "Examining Levels and Factors of Speaking Anxiety among EFL Libyan English Undergraduate Students," Int. J. Appl. Linguist. English Lit., vol. 7, no. 5, p. 47, 2018, doi: 
10.7575/aiac.ijalel.v.7n.5p.47.

[32] F. Alnahidh and S. Altalhab, "The Level and Sources of Foreign Language Speaking Anxiety among Saudi EFL University Students," $A d v$. Lang. Lit. Stud., vol. 11, no. 1, p. 55, 2020, doi: 10.7575/aiac.alls.v.11n.1p.55.

[33] K. Sugiyati and L. Indriani, "Exploring the Level and Primary Causes of Public Speaking Anxiety Among English Department Students," J. Res. Lang. Educ., vol. 2, no. 1, p. 57, 2021, doi: 10.33365/jorle.v2i1.906. 